\title{
국가갈등관리의 효율화 방안 \\ - 화물연대파업을 중심으로 - \\ Improving the National Conflict Management System in Korea \\ - Trucker's Strike in 2003 as Complex Conflict -
}

변성수, 이재은

충북대학교 국가위기관리연구소 ${ }^{*}$ 충북대학교 행정학과**

Sung-Soo Byun(bss@chungbuk.ac.kr)*, Jae-Eun Lee(jeunlee@chungbuk.ac.kr)**

\section{요약}

이 논문의 목적은 갈등과정의 심화 · 확대 단계를 분석하여 국가갈등관리의 문제점을 해결할 수 있는 방 안을 도출하는데 있다. 연구목적 달성을 위하여 이 논문에서는 국가갈등관리의 정책대상영역으로서 갈등 발생원인, 갈등피해영역, 갈등관리기구, 갈등관리전략, 갈등관리 장애요인을 다루고 있으며, 복합갈등으로 서 화물연대 파업 사례를 분석하였다. 끝으로, 이 연구는 국가갈등관리의 효율화 방안으로 국가갈등관리 전담기구의 설치, 국가갈등관리 지표개발, 갈등단계와 외부환경에 따른 갈등관리 매뉴얼 개발, 갈등관리기 구간 협조체계 구축 등을 제시하였다.

- 중심어 : | 국가갈등 | 국가갈등관리 | 화물연대파업 |

\section{Abstract}

This article aims to derive problems of the national conflict management from analyzing aggravation and spread stage in conflict process and to improve the national conflict management. For achieving the purpose, this article deals with sources of conflict, conflict damage, conflict management institutions, conflict management strategies, and the obstacles of conflict management as the domain of policy target in the national conflict management. This paper, also, analyzes the trucker's strike in 2003 as a complex conflict. Finally, the improvement of national conflict management needs to establish the specialized organization for conflict management, to develop indicators and manuals according to conflict stage and environment.

keyword : | National Conflict | National Conflict Management | Trucker's Strike |

\section{I. 서 론}

갈등은 인간의 상호작용 과정에서 통상적으로 발생 하는 결과이다[1]. 인류사회는 갈등의 해결을 통하여 발 전해왔으며, 인류의 역사는 이러한 갈등해결의 연속적 과정이라고 할 수 있다.
현대사회의 다원화가 진행됨에 따라 다양한 목표와 이익을 추구하는 새로운 사회적 집단이나 조직들이 생 성되고 있고 있으며, 이는 한정된 자원의 획득과 목표 달성을 위한 조직들 간의 첨예한 대립으로 이어지고 있 다. 특히, 현대사회에서 발생하는 갈등 유형에는 갈등당 사자뿐만 아니라 갈등당사자와 직 - 간접적으로 관련이
접수번호 : \#081201-001

접수일자 : 2008년 12월 01일
심사완료일 : 2009년 01월 16일

교신저자 : 이재은, e-mail : jeunlee@chungbuk.ac.kr 
있는 이해관계자, 이들이 속한 계층적·지역적 범위 및 일반 국민에게 까지 영향을 미치는 국가적 차원의 갈 등, 즉 국가갈등도 포함된다.

이 연구는 이러한 국가갈등에 관한 이론적 논의와 사 례분석(2003년 5월 화물운송 특수고용직 노동자연대 제 1 차 총파업, 이하 화물연대파업)을 통하여 국가갈등 을 효율적으로 관리할 수 있는 국가갈등관리의 개념과 영역, 방안을 모색하는데 목적이 있다.

\section{II. 국가갈등관리에 대한 이론적 논의}

\section{1. 국가갈등관리의 의의}

갈등은 다양한 심리적 - 행태적 양상과 상황적 - 과정 적 유형과 관련한 용어를 포함하는 상위 개념체계의 한 부분으로 이해할 수 있다[2]. 그리고 갈등은 개인 · 집 단 - 조직 등의 내부 또는 상호 간의 대립적 상호작용으 로 정의할 수 있으며[3][4], 자신의 이익이 다른 사람에 의해 부정적인 영향을 받는 것을 인지하는 과정으로도 이해할 수 있다[5]. 이러한 갈등은 그 목적과 방향이 끊 임없이 변화하기 때문에 매우 역동적이며[6], 역동적 과 정에는 심화와 확대 등을 통하여 갈등 피해 규모가 변 화하는 경우를 포함한다. 이 변화된 갈등 중에는 갈등 피해의 범위와 강도가 국가적 차원에서 정치적 - 경제 적·사회구조적·제도적, 그리고 국민의식 및 행태에 변화를 일으키는 갈등이 존재하며, 이러한 갈등이 바로 국가갈등이다.

갈등은 어떻게 관리하느냐에 따라 긍정적 - 생산적 또는 부정적 · 비생산적인 결과를 가져온다[7]. 특히, 잘 못된 갈등해결은 모든 사람에게 경제적 - 도덕적 제재 를 가져오기 때문에[8], 갈등관리는 갈등 당사자들이 모 두 상생할 수 있도록 이루어져야 한다[9]. 갈등관리는 관리적 통제를 통한 사회유지, 상이한 사회적 목적추구 에 대한 관리개혁, 현행 자원배분 유형에 관한 근본적 변화 등에 활용된다[10]. 따라서 국가갈등관리는 국가 갈등의 예방, 국가갈등의 피해범위 및 강도의 최소화, 국가갈등의 효율적 해결 등을 통한 국가적 - 사회적 발 전을 내용으로 한다.
국가갈등 상황에서 갈등당사자들은 자신의 이익을 최대화하고 손해를 최소화하려는 경향이 있다. 이는 갈 등의 신속한 해결과 지속적 관리의 방해요소로 작용한 다. 이에 제 3 자의 개입을 통한 해결이 필요하며, 제 3 자 로서 정부가 가장 적합하다. 정부는 갈등상황 파악에 필요한 전문성과 인력 및 자원 확보에 용이하며, 강력 한 전략 추진을 위한 강제력을 갖고 있기 때문이다. 이 에 국가갈등관리란 정부의 주도하에 국가갈등을 효율 적으로 해결하고 예방하는 지속적인 관리과정으로 정 의할 수 있다.

\section{2. 국가갈등관리의 정책대상영역}

\section{1 갈등발생원인}

갈등의 발생원인으로 상호의존성, 목표의 차이, 환경 과의 밀접성 등이 있다. 상호의존성이란 둘 이상의 조 직이 목표달성을 위해 상호간의 협조 - 정보제공 - 동조 또는 협력행동을 필요로 하는 정도로서, 상호의존성의 정도가 크면 클수록 갈등을 일으킬 기회는 많아지며, 조직간 갈등도 현실적인 상호의존성과 관련이 크다 [11]. 또한 목표와 관련된 개인, 집단 및 조직 전체의 욕 구는 현재 지니고 있는 수단을 통해 모두 충족시키기는 어렵다. 이는 자원의 희소성 문제이며 이를 해결하기 위한 조직의 활동은 갈등과 직접적인 관계가 있다. 서 로 다른 조직들간에 목표의 차이로 인한 자원(수단)의 희소성(한계성)은 조직간 갈등의 원인이 된다[12]. 그리 고 조직과 환경의 밀접성 정도에 따라 갈등이 발생한 다. 조직과 환경의 관계가 복잡하고 이질적이고 불확실 할수록 외부에서 발생하는 갈등이 증가하기 때문이다.

\section{2 갈등피해영역}

갈등피해영역은 국가갈등관리정책의 대상이 되는 갈 등의 중요 판단 기준이 된다. 갈등피해영역은 갈등피해 의 범위와 강도를 대응하여 설정할 수 있으며, 이는 [그 림 1]과 같다. 


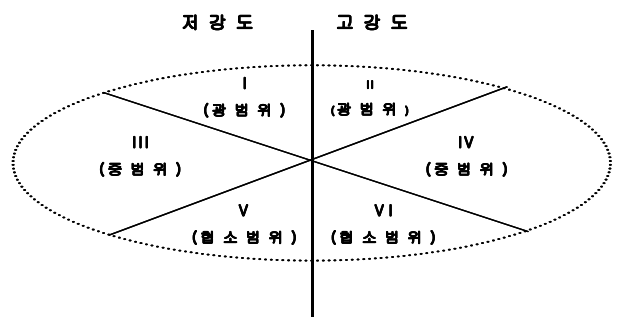

${ }^{*}$ 자료 : 이재은 $(1999,138)$ 참조.

그림 1. 갈등피해영역 모형

갈등피해의 범위는 갈등피해가 미치는 지역적 - 계층 적 영향 범위를 의미하며, 갈등피해의 강도는 갈등이 유발하는 경제적 - 사회적 손실 비용의 정도를 나타낸 다. 갈등피해영역을 조합하면 [표 1]과 같다.

표 1. 국가갈등관리정책의 갈등피해영역 조합

\begin{tabular}{|c|c|c|c|c|}
\hline \multicolumn{2}{|c|}{ 구분 } & \multicolumn{3}{|c|}{ 갈등피해의 범위 } \\
\cline { 3 - 5 } \multicolumn{2}{|c|}{} & 광범위 & 중범위 & 협소범위 \\
\hline \multirow{2}{*}{ 갈등피해의강도 } & 저강도 & 조합 I & 조합 III & 조합V \\
\cline { 2 - 5 } & 고강도 & 조합II & 조합IV & 조합VI \\
\hline
\end{tabular}

*자료 : 이재은(1999, 138) 참조.

\subsection{1 조합 I 과 조합ㅍ}

조합 $\Pi$ 는 범위가 넓고 강도가 높은 조합으로서 정책 의 대상영역이 된다. 조합 I 은 갈등의 심각성이 적고 갈등인식이 어려우나, 갈등피해의 범위가 광범위로서 갈등피해는 국가적 - 광역적 지역범위에 영향을 미친 다. 이에 조합 I 또한 정책의 결정자나 참여자에 의해 선택적으로 대상영역이 될 수 있다.

\subsection{2 조합표과 조합 $\mathrm{V}$}

조합피은 갈등피해의 강도가 낮고 범위는 갈등당사 자와 이해관계자 및 단일지역사회이기 때문에 갈등당 사자간의 해결이 효율적이다. 그러나 갈등피해의 고강 도는 시간의 경과에 따라 피해범위와 갈등인식을 확산 시킬 수 있기 때문에, 조합 $\mathrm{V}$ 는 조합포 변화할 가능 성이 있다. 따라서 조합 $\mathrm{IV}$ 는 국가갈등관리의 국가갈등 예방차원에서 국가갈등관리 정책의 대상영역이 된다.

\subsection{3 조합V과 조합VI}

조합 $\mathrm{V}$ 는 범위가 개인, 집단, 조직의 미시적 수준이고 강도도 낮기 때문에 정책대상영역에서 제외된다. 그러 나 조합VI는 선택적으로 국가갈등관리 정책의 대상영 역이 될 수 있다. 피해범위가 협소하지만 피해의 강도 가 생존과 관련되거나 언론이나 여론 등에 의해 이슈화 될 때 국가갈등관리 정책의 대상영역이 될 수 있다.

\section{3 갈등관리기구}

갈등관리기구는 갈등을 관리하거나 해결을 목표로 하는 공식적 - 비공식적 제도나 기관을 말하며, 중앙행 정기관 수준의 갈등관리기구와 갈등분야별 분쟁조정제 도 등이 있다[14].

\subsection{1 중앙행정기관 수준의 갈등관리기구}

중앙행정기관 수준의 갈등관리기구는 정책조정기능 을 수행하는 정부 내 조정기제를 말한다. 정부 내 공식 적 조정기제로는 국무회의, 국정현안정책조정회의, 주 무장관회의, 4 대분야별 장관회의, 차관회의, 청와대비 서실, 국무조정실 등이 있다. 비공식적 기구로는 당정협 의회와 실무조정협의회 등이 있다.

\subsection{2 갈등분야별 분쟁조정제도}

갈등분야별 분쟁조정제도는 갈등상황의 당사자들이 상호간 수용가능한 해결책을 찾고자 하는 협력적인 갈 등해결제도이다. 갈등분야별 분쟁조정 관련 기구 및 법 규현황은 다음 [표 2]와 같다.

\section{표 2. 분쟁조정 관련 기구 및 법규현황}

\begin{tabular}{|c|c|c|c|}
\hline 구분 & 기구 & 관련법규 & 관련부처기관 \\
\hline \multirow{2}{*}{ 노동 } & 노사정위원회 & $\begin{array}{c}\text { 노사정위원회의설치및운 } \\
\text { 영등에관한법률 }\end{array}$ & 노사정위원회 \\
\hline & 중앙노동위원회 & $\begin{array}{c}\text { 노동조합및노동관계조정 } \\
\text { 법, 노동위원회법 }\end{array}$ & 노동부 \\
\hline 외교 & $\begin{array}{l}\text { 국제계약분쟁 } \\
\text { 조정위원회 }\end{array}$ & $\begin{array}{c}\text { WTO 정부조달협정, } \\
\text { 국가를당사자로하는계약 } \\
\text { 에관한법률 }\end{array}$ & 외교통상부 \\
\hline 건설 & $\begin{array}{l}\text { 건설분쟁 } \\
\text { 조정위원회 }\end{array}$ & 건설산업기본법 & 건설통상부 \\
\hline
\end{tabular}

* 자료 : 지속가능발전위원회(2004, 93) 참조. 


\section{4 갈등관리전략}

\subsection{1 협상(negotiation)}

협상은 갈등당사자들의 주도하에 갈등을 해결하는 가장 효율적인 전략이다. 협상은 각자의 의견과 자료를 교환하며 해결의 방법이나 합의를 도출하는 것이므로 갈등해결과정에서 기본적 역할을 수행한다고 할 수 있 다[15][16].

\subsection{2 조정(mediation)}

조정은 조정자가 갈등당사자들의 동의를 얻어 효율 적인 협상을 할 수 있도록 도와주는 전략이다. 조정자 의 역할은 효과적인 의사교환, 갈등의 명확화, 잠재적 이익과 관심사항의 구체화, 갈등해결의 접근방법 개발 등이 있다. 조정은 비공개진행, 비밀유지, 분쟁당사자와 조정자에 의한 통제, 미래지향적 과정 등 다양한 특성 을 가지고 있다[15].

\subsection{3 중재(arbitration)}

중재란 중재자의 판정에 의해 갈등을 최종적으로 해 결하는 제도라고 정의할 수 있다[15][16]. 중재는 강제 적으로 갈등을 해결한다는 점에서 재판과 유사하며, 갈 등당사자의 자주적 의사에 기초를 두며, 다양한 사회관 행이나 관습법 및 형평과 선에 의하여 판단이 이루어진 다는 측면에서 조정과 유사하다. 즉 중재는 재판과 조 정의 중간적 위치에 있는 갈등해결전략이다[15-18].

\section{5 갈등관리 장애요인}

\subsection{1 갈등관리교육 및 협상능력 부족}

갈등관리교육 및 협상능력은 갈등의 예방과 해결, 그 리고 갈등피해의 최소화를 위해 매우 중요하다. 실제 갈등상황에서 협상능력의 부족은 갈등해결의 지연을 초래하거나 갈등을 악화시키기도 한다.

\subsection{2 커뮤니케이션 채널의 부재}

커뮤니케이션은 갈등의 표현과 인지 그리고 갈등해 결을 위한 갈등 당사자간의 의사소통을 의미한다. 커뮤 니케이션 채널의 부재나 간헐적 확보는 갈등을 심화시 키거나 갈등해결의 지연, 갈등피해의 증폭과 갈등 당사
간의 상호불신, 교환정보의 왜곡 등은 효율적 의사전달 을 방해할 수 있다[19].

\subsection{3 갈등해결(협상) 전문가의 부족}

갈등당사자들은 당사자간의 원만한 갈등해결이 이루 어지지 않는다면, 제 3 자의 조력을 받아 갈등을 해결할 수 있도록 갈등해결(협상) 전문가가 필요하며[20], 전문 가의 부족은 갈등해결을 지연시킨다.

지금까지의 논의를 종합하여 보면 국가갈등관리 정 책의 대상영역은 조합ㅁㅇㅇ 조합IV가 되며, 선택적으로 조합 I 과 조합VI이 대상영역에 포함될 수 있다.

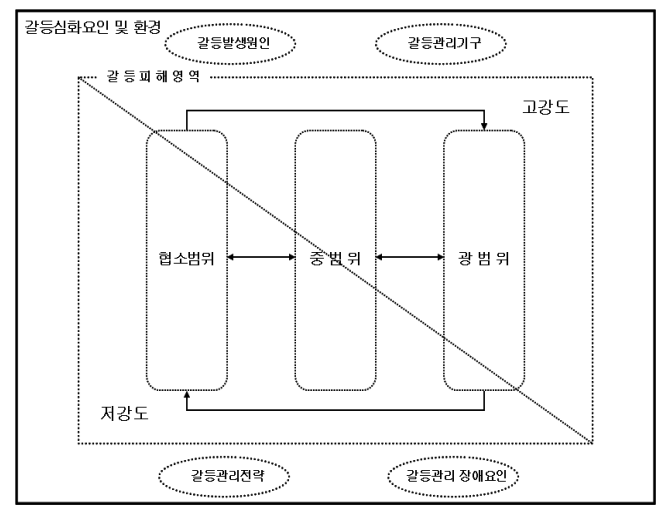

그림 2. 국가갈등관리 정책대상 영역

\section{3. 갈등관리 연구 경향}

갈등관리에 관한 주요 연구들은 갈등의 종류를 기준 으로 정책갈등, 지역갈등, 노사갈등, 계층갈등, 환경갈 등, 조직갈등 등으로 구분되어 연구가 진행되고 있다. 또한, 공익을 기준으로 공공사업의 추진과정에서 정부 와 주민사이에서 발생하는 공공갈등에 관한 연구가 대 두되고 있다.

이 연구는 갈등발생원인, 갈등피해영역, 갈등관리기 구, 갈등관리전략, 갈등관리 장애요인 등 갈등영역을 기 준으로 국가갈등에 관한 이론적 접근과 이를 효율적으 로 관리할 수 있는 방안을 모색하고자 한다. 


\section{III. 국가갈등관리에 대한 사례분석: 화물연대파 업의 쟁점별 분석}

\section{1. 화물연대파업 개관}

화물연대파업은 화물연대 포항지부와 경남지부의 파 업을 시작으로 부산지부, 광주 - 전남지부, 경인지부 등 전국적으로 확산된 화물연대 집단운송거부사태이다. 화물연대파업은 물류대란이라는 국가갈등으로 발달하 였으며, 이는 경제적 - 사회적으로 엄청난 피해를 초래 하였다. 또한 정부의 미흡한 대처로 인하여 화물연대요 구안의 무조건적인 수용과 함께, 그 부담은 국민에게 돌아가게 되는 결과를 가져왔다.

\section{2. 갈등발생원인}

화물연대파업의 발생원인은 물류시스템의 구조, 비 정규직 문제, 에너지 세제 개편 등으로 파악할 수 있으 며, 내용은 [표 3]과 같다.

\section{표 3. 화물연대파업의 발생원인 및 내용}

\begin{tabular}{|c|l|}
\hline 발생원인 & \multicolumn{1}{|c|}{ 내용 } \\
\hline $\begin{array}{c}\text { 물류시스템의 } \\
\text { 구조 }\end{array}$ & $\begin{array}{l}\text { 지입제를 합법화(97년 화물자동차운수사업법) } \\
\text { 운송료의 4 10\%정도의 위탁수수료와 3 4단계 } \\
\text { 위탁시 } 60 \sim 70 \% \text { 베 불과한 운송요금을 수령하게 } \\
\text { 되는 불합리한 구조인 다단계 알선 }\end{array}$ \\
\hline $\begin{array}{c}\text { 비정규직 } \\
\text { 문제 }\end{array}$ & $\begin{array}{l}\text { 1997년 경제위기 이후 구조조정, 위수탁, 차량불하 } \\
\text { 등을 정규직에서 비정규직화 됨 }\end{array}$ \\
\hline $\begin{array}{c}\text { 에너지 세제 } \\
\text { 개편 }\end{array}$ & $\begin{array}{l}\text { 2001년 산업자원부의 '에너지세제개편' 에 따라 } \\
\text { 사업용 차량의 연료에 특별소비세와 교통세 부과 }\end{array}$ \\
\hline
\end{tabular}

* 자료 : 라영재·김세진(2003, 397-400) 참조.

화물연대파업은 임금인상이나 근무조건 - 환경의 개 선, 노조의 경영참여 등을 원인으로 하는 일반적인 노 사갈등과 상당한 차이를 지니고 있다. 화물연대파업은 물류체계와 비정규직 문제, 에너지 세제 개편 등 정책 적 - 제도적 측면이 원인으로서 정부정책에 대한 불만 과 정부의 미흡한 대처로 인해 갈등이 심화되었으며, 이후 국가갈등으로 확대되었다.

\section{3. 갈등피해영역}

화물연대파업의 피해영역은 지역적 범위, 경제적 측 면과 사회적 측면으로 구분하여 살펴볼 수 있으며, 내
용은 [표 4]와 같다.

표 4. 화물연대파업의 피해영역

\begin{tabular}{|c|l|}
\hline 피해영역 & \multicolumn{1}{|c|}{ 내용 } \\
\hline 지역적 범위 & $\begin{array}{l}\text { 부산, 포항 및 경상남도, 광양 및 전라남도, 인천, 경기도 } \\
\text { 등 전국 }\end{array}$ \\
\hline 경제적 측면 & $\begin{array}{l}\text { 운송선적 차질에 의한 피해액 } 5 \text { 억 } 4000 \text { 만달러 } \\
\text { 중소기업 } 172 \text { 개 업체 } 3300 \text { 만달러 }\end{array}$ \\
\hline 사회적 측면 & $\begin{array}{l}\text { 파업만능주의 확산 } \\
\text { 타 교통수단과의 형평성 문제 } \\
\text { 국민의 국가경제에 대한 불안감과 정부에 대한 불신 }\end{array}$ \\
\hline
\end{tabular}

피해의 지역적 범위는 포항 - 경남지부와 광주 · 전남 지부, 부산지부, 경인지부 등이 속한 지역뿐만 아니라, 이와 연계되어 있는 화물운송 관련 기지 지역, 이들을 이용하는 공장지역 등 전국으로 확대되었다. 화물연대 파업에 따른 경제적 피해영향을 살펴보면 철강(2,023억 원), 섬유(2,000억원), 전자(1,500억원), 타이어(325억원) 등이며, 특히, 부산항과 광양항은 수출 컨테이너의 터미 널 사용료의 감소로 인하여 하루에 각각 6 억 7000 만원 과 9 천만 원의 피해를 입은 것으로 나타났다[22]. 이로 인해 국가경제의 대외신인도가 크게 떨어졌다. 사회적 피해인 파업만능주의는 국가 기강을 무너뜨리고 다른 근로자들의 근로의욕을 상실하게 하였다. 또한, 정부의 화물연대 요구안 수용은 버스나 택시와 같은 다른 교통 수단과의 형평성 문제가 제기된다. 그리고 화물연대파 업 사태에 대하여 국민들은 정부의 책임이 크다고 생각 하고 있다. 이는 정부의 위기대응 능력 미흡과 국가경 제에 대한 국민들의 실망과 불안감을 초래하였다. 지금 까지 화물연대파업의 피해영역을 살펴본 결과, 화물연 대파업 피해의 지역적 범위는 전국적인 것으로 나타났 다. 그리고 경제적으로 국가, 기업 등에게 막대한 손실 과 사회적으로 국민의 정부에 대한 불신, 국가경제에 대한 불안감 등을 초래하였다. 이로써 화물연대파업은 광범위 · 고강도 조합인 국가갈등인 것으로 판단된다.

\section{4. 갈등관리기구}

화물연대파업과 관련한 사전적 갈등관리기구에는 노 사정위원회와 중앙노동위원회, 노동부가 있었고, 사후 적 갈등관리기구는 관련부처로 구성된 통합협상기구가 
있었으며, 각각의 역할은 [표 5]에서와 같다.

\section{표 5, 화물연대파업의 관리기구}

\begin{tabular}{|c|l|}
\hline 구분 & \multicolumn{1}{|c|}{ 역할 } \\
\hline 노사정위원회 & $\begin{array}{l}\text { 전국 규모의 이익집단이 참여하여 당면한 정차경제 } \\
\text { 적 위기를 극복하기 위한 거시적 국가정책의 조정 }\end{array}$ \\
\hline 중앙노동위원회 & $\begin{array}{l}\text { 노사관계에서 발ㅅㅐㅐ하는 각종 분쟁에 대하여 신속하 } \\
\text { 고 공정하게 처리할 수 있는 국가기관 }\end{array}$ \\
\hline \multirow{2}{*}{ 노동부 } & $\begin{array}{l}\text { 노사관계에 직간접적으로 관여하여 노사갈등을 예 } \\
\text { 방하고, 갈등이 발생하면 신속히 갈등을 해결하는 } \\
\text { 기능을 담당 }\end{array}$ \\
\hline 통합협상기구 & $\begin{array}{l}\text { 건설교통부행정자치부산업자원부노동부 등의 부처 } \\
\text { 로 구성되 임시 협상기구로서 회물연대파업의 실질 } \\
\text { 적인 관리기구의 역할수행 }\end{array}$ \\
\hline
\end{tabular}

노사정위원회, 중앙노동위원회, 노동부 등은 국가정 책에 대한 화물연대의 요구 조건 등에 대하여 조정을 통해 갈등을 예방하거나 해결할 수 있었으나 기능을 제 대로 발휘하지 못하였다. 특히, 화물연대파업이 물류대 란으로까지 심화되는 원인중의 하나는 갈등발생초기에 이를 담당할 갈등관리기구가 없었다는 것이다. 그리고 화물연대파업 사태가 심각한 상태에 이르러서야 화물 연대가 요구하는 사안과 관련이 있는 당시 건설교통 부 - 행정자치부 - 산업자원부 - 노동부 등의 부처로 구 성된 임시 협상기구가 만들어졌다. 이러한 협상기구는 협상경험의 부족과 협상능력의 저하, 협상에 관한 일관 된 원칙 등이 없었기 때문에 화물연대의 요구조건을 대 부분 수용하게 되는 결과를 낳았다.

\section{5. 갈등관리전략}

화물연대파업에 따른 정부의 갈등관리전략은 협상과 위협 그리고 보상이었으며, 그 내용은 [표 6]과 같다.

\section{표 6. 화물연대파업의 관리전략}

\begin{tabular}{|l|l|}
\hline 구분 & \multicolumn{1}{|c|}{ 내용 } \\
\hline \multirow{2}{*}{ 협상 } & $\begin{array}{l}\text { 화물연대 포항지부의 파업발생부터 부산지부의 협상타결까지 } \\
\text { 회물연대파업의 전체과정에서 활용 }\end{array}$ \\
\hline \multirow{3}{*}{ 위협 } & $\begin{array}{l}2003 \text { 년 } 5 \text { 월 12일 정부는 파업 중인 부산지부 조합원들이 정 } \\
\text { 부의 비상수송을 방해할 경우 공권력을 행사하기로 결정 } \\
2003 \text { 년 } 5 \text { 월 } 13 \text { 일 재개된 노정협상에서 정부는 회물연대의 선 } \\
\\
\text { 정상화 후협상이라는 강경책을 선택 }\end{array}$ \\
\hline 보상 & 12 개의 요구안 중 산별교섭의 제도화를 제외한 11 개를 수용 \\
\hline
\end{tabular}

정부의 협상능력 부족과 일관되지 못한 협상태도, 화 물연대의 협상합의안에 대한 번복 등은 오히려 갈등을 심화시키는 결과를 초래하였다. 또한, 잦은 협상결렬은 갈등해결의 지연을 초래하여 갈등의 피해규모를 증가 시키는 원인으로 작용하였다. 화물연대파업과 같은 국 가갈등은 조정과 중재가 적합하다. 특히, 중재는 강제성 이 있기 때문에 신속한 갈등해결에 효과적이다.

\section{6. 갈등관리 장애요인}

화물연대파업의 갈등관리 장애요인은 정부의 협상능 력 부족과 인식 차이, 갈등해결 전문가, 커뮤니케이션 채널 등으로 구분할 수 있으며, 내용은 [표 7]과 같다.

\section{표 7. 화물연대파업의 장애요인}

\begin{tabular}{|c|l|}
\hline 구분 & \multicolumn{1}{|c|}{ 내용 } \\
\hline 협상능력부족 & $\begin{array}{l}\text { 정부의견의 미반영과 화물연대 요구안의 대부분 } \\
\text { 수용 }\end{array}$ \\
\hline 인식의 차이 & 파업에 대한 화물연대와 정부의 관점.입장 차이 \\
\hline 갈등해결 전문가 & 외부 갈등해결전문가의 부족 \\
\hline 커뮤니케이션 채널 & $\begin{array}{l}\text { 협상주체의 모호성으로 인한 커뮤니케이션 대상 } \\
\text { 및 채널 미확정 }\end{array}$ \\
\hline
\end{tabular}

화물연대와의 협상과정에서 정부는 협상능력의 부족 으로 인해 주도권을 화물연대에게 빼앗기는 양상을 보 였으며, 정부와 화물연대간의 입장 차이를 좁히지 못하 였다. 정부와 화물연대간의 인식차이는 갈등을 심화시 키는 갈등관리의 장애요인이다. 화물연대는 자신의 생 존권 사수라는 입장이었던 것에 비해, 정부는 매년 발 생하는 파업의 일부분이라는 인식이 지배적이어서, 정 부의 미흡한 대응을 초래하게 되었다. 화물연대파업에 서 갈등해결 전문가의 부족과 커뮤니케이션 채널의 부 재도 갈등관리 장애요인으로 작용하였다. 정부내에 화 물연대파업과 같은 복합갈등을 해결할 수 있는 전문부 서 및 외부 전문가가 없었다. 또한, 화물연대파업의 초 기단계에서 교섭자체가 제대로 이루어지지 않은 사실 에서 알 수 있듯이 갈등초기단계에서 커뮤니케이션 채 널이 없었다. 


\section{IV. 국가갈등관리의 효율화 방안}

\section{1. 국가갈등관리 전담기구의 설치}

국가갈등관리체계의 효과적인 운영과 갈등관리 정책 의 실효성을 높이며, 갈등관리기구간 원활한 협의 - 조 정이 이루어지기기 위해서는 현재의 정책수립 기능과 정책집행 기능을 통합할 수 있는 국가갈등관리 전담기 구를 설치하여야 한다.

국가갈등관리 전담기구의 정책수립은 갈등의 원인과 성격을 파악하여, 이를 토대로 갈등해결을 위한 접근법 과 방안, 갈등예방 등을 도출하여 제도적으로 정착시키 는 것을 말한다. 또한, 갈등관리 정책수립을 지원하고 보조할 수 있는 정책대안 개발 및 지원과 갈등 모니터 링 기능을 국가갈등관리 전담기구에 포함시켜야 한다. 정책집행은 갈등의 유형이 단일갈등사안인지, 복합갈 등사안인지를 판단한 후에 이루어져야 한다. 단일갈등 사안을 담당하는 관리기구는 크게 정책갈등, 지역갈등, 노사갈등, 계층갈등, 환경갈등 등으로 구분할 수 있으 며, 복합갈등사안은 단일갈등관리기구의 인원으로 구 성된 TFT형의 복합갈등관리기구가 담당한다.

\section{2. 국가갈등관리의 지표 개발}

국가갈등관리의 지표는 갈등의 변화를 파악하고 이 에 대응할 수 있는 정책수립과 갈등관리전략 선택에 필 요한 정보를 제공하기 때문에 매우 중요하다. 특히, 갈 등이 발생하여 국가갈등으로 발달하기 전 단계인 갈등 심화 단계를 측정하여 정부가 개입하는 시기를 결정할 수 있도록 하는 지표가 매우 중요하다.

국가갈등관리 지표는 국가갈등영역을 토대로 개발할 수 있으며, 지표체계의 기본적 영역은 갈등발생원인, 갈 등관리 장애요인, 갈등피해, 갈등관리기구, 갈등관리전 략으로 구성된다. 갈등발생 원인의 세부항목에는 상호 의존성, 자원의 한계, 목표의 차이, 정보의 불충분, 환경 의 연계성 등으로 구성된다. 갈등피해영역은 갈등의 범 위와 강도이며, 세부항목은 광범위 - 고강도 조합, 중범 위·고강도 조합, 광범위 - 저강도 조합, 협소범위·고 강도 조합으로 구성된다. 갈등관리기구는 중앙부처에 서의 갈등관리기구와 분야별 분쟁조정 기구로 구성하
며, 갈등관리전략은 협상, 조정, 중재 등의 9 가지 전략 으로 구성할 수 있다. 마지막으로, 갈등관리 장애요인의 세부항목은 갈등관리 교육의 부족, 협상능력의 부족, 커 뮤니케이션의 부재, 인식의 차이, 갈등해결 전문가의 부 족 등으로 구성한다.

\section{3. 갈등단계와 외부환경에 따른 갈등관리 매뉴얼 개발}

갈등단계에 따른 갈등관리전략의 선택은 갈등해결에 직접적인 영향을 미치기 때문에 매우 중요하다. 우선, 갈등발생단계에서는 갈등당사자간의 자율적인 갈등해 결을 위하여 협상이 매우 바람직하다. 갈등의 확대단계 에서는 국가갈등 예방을 위하여 협상보다는 갈등해결 을 신속하게 이끌어 낼 수 있는 조정과 중재가 필요하 다. 그러나 중재는 강제력을 가지고 있어 갈등당사자들 의 불만을 초래할 수 있으며, 갈등을 증폭시킬 수 있기 때문에 갈등의 확대단계에서는 중재보다 거부감이 적 은 조정이 적합하다. 마지막으로, 국가갈등단계에서는 갈등피해가 심각하기 때문에 갈등의 신속한 해결을 위 하여, 강제력이 있는 중재가 갈등관리전략으로 적합한 것으로 판단된다.

갈등상황은 외부환경의 영향을 받기 때문에, 갈등단 계만 가지고 갈등관리전략을 선택하는 것은 갈등관리 의 실패를 초래할 수 있다. 갈등관리전략은 갈등단계와 외부환경을 고려하여 갈등상황에 적합하게 선택을 해 야 한다. 따라서 갈등단계와 외부환경에 따른 갈등관리 전략의 매뉴얼을 개발하여야 하며, 갈등관리지표와도 연계되어야 한다.

\section{4. 갈등관리기구간 협조체계 구축}

복합갈등의 해결을 위해서는 관련 갈등관리기구간 협조가 필요하며, 이는 갈등관리기구간 협조체계를 제 도적으로 구축해야 한다. 협조체계의 구축은 갈등관리 기구의 협의 · 조정 활동의 실효성 확보에 중점을 두고 진행되어야 한다. 특히, 복수의 갈등관리기구가 관련된 갈등에 대해서는 갈등관리전략의 선택과 집행 이전에 갈등관리기구간 협의와 조정이 이루어 질 수 있도록 협 
의 조정을 의무화하고 그 준수여부를 항상 감독하여 야 한다.

그리고 갈등사안에 따른 역할과 권한범위 등 갈등관 리기구간 관할권을 법적 - 제도적으로 명확히 설정하여 야 한다. 갈등관리기구의 역할과 권한의 한계가 불분명 하게 설정되어 있거나 중복이 되어 있으면, 복합갈등의 해결이 어려우며 갈등관리기구간 갈등이 발생할 수 있 기 때문이다. 또한, 갈등관리기구간 관할권 설정은 갈등 사안과 갈등관리기구의 특성을 고려하여 역할과 권한 범위를 통합하거나 재편성하여야 한다.

마지막으로, 갈등관리기구의 갈등관리전략 수립과 집행을 사전에 협의 - 조정하기 위해서는 갈등관리기구 간 커뮤니케이션 채널을 확보해야 한다. 갈등관리기구 들은 커뮤니케이션 채널을 통해 갈등사안에 따른 서로 간의 정책지향점과 관할범위에 관한 정보나 의견을 교 환할 수 있다. 커뮤니케이션 채널은 갈등의 성격이나 유형에 따라 임시적 · 상시적으로 운영한다.

지금까지 제시한 국가갈등관리의 효율화 방안을 정 리하면 다음 [표 8]과 같다.

\section{표 8. 국가갈등관리의 효율화 방안}

\begin{tabular}{|c|c|}
\hline 구분 & \multicolumn{1}{|c|}{ 내용 } \\
\hline 전담기구 설치 & 갈등관리 정책수립과 정책집행 기능 통합 \\
\hline 지표개발 & 갈등심화 단계 측정 \\
\hline 관리 매뉴얼 개발 & 갈등단계와 외부환경 변화에 따른 관리전략 \\
\hline 협조체계 구축 & $\begin{array}{l}\text { 갈등관리기구간 협의조정과 역할 및 권한범위 } \\
\text { 설정 }\end{array}$ \\
\hline
\end{tabular}

\section{V. 결론}

우리나라의 국가갈등관리체계는 갈등관리를 위한 정 책수립과 정책집행이 이원화되어 있고, 갈등관리기구 간 협조체계의 미흡, 갈등관리기구의 전문성 결여 등으 로 인해 불완전한 것으로 판단된다. 따라서 국가갈등관 리의 효율성을 제고하기 위해서는 갈등관리정책의 수 립과 집행에 대한 단일화와 정부의 적극적 개입 시점을 파악할 수 있는 지표 개발, 신속한 대응을 위한 갈등관 리 매뉴얼 개발 등이 우선되어야 한다. 결국 이는 국가
갈등관리전담기구의 설치를 통하여 해결하는 것이 가 능하다. 또한, 갈등관리기구간 협조체계 구축을 위해서 는 갈등관리기구간 협의 · 조정의 의무화 및 감독, 관할 권의 재설정, 커뮤니케이션 채널의 확보 등이 필요하다. 갈등해결에 있어 자원의 효율성을 높이기 위해서는 분 야별 분쟁조정제도의 활성화가 이루어져야 한다. 갈등 에 대한 인식의 변화와 갈등관리 장애요인의 제거, 갈 등해결을 위한 올바른 협상문화의 정착, 갈등관리기구 의 전문성 확보 등을 위해서는 갈등관리 교육체계를 구 축하는 것이 필요하다.

\section{참 고 문 헌}

[1] C. B. Derr, "Managing Organizational Conflict: Collaboration, Bargaining, and Power Approaches," California Management Review, Vol.21, No.2, pp.76-83, 1978.

[2] C. F. Fink, "Some Conceptual Difficulties in the Theory of Social Conflict," Journal of Conflict Resolution, Vol.12, No.4, pp.412-460, 1968.

[3] W. J. Duncan, Organizational Behavior, 2nd ed, Boston : Houghton Mifflin Co, 1981.

[4] S. P. Robbins, "Conflict Management and Conflict Resolution Are Not Synonymous Terms," California Management Review, Vol.21, No.2, pp.67-75, 1978.

[5] J. A. Jr. Wall and R. R. Callister, "Conflict and its management," Journal of Management, Vol.21, No.3, pp.515-558, 1995.

[6] S. M. Schmidt \& T. A. Kochan, "Conflict: Toward Conceptual Clarity," Administrative Science Quarterly, Vol.17, No.3, pp.359-370, 1972.

[7] R. L. Fitzpatrick, "A Literature Review Exploring Values Alignment as a Proactive Approach to Conflict Management," International Journal of Conflict Management, Vol.18, No.3, 
pp.280-305, 2007

[8] A. D. Slabbert, "Conflict Management Styles in Traditional Organizations," The Social Science Journal, Vol.41, No.1, pp.83-92, 2004.

[9] J. Davidson \& C. Wood, "A Conflict Resolution Model," Theory Into Practice, Vol.43, No.1, pp.6-13, 2004.

[10] M. A. Chesler and J. E. Crowfoot \& B. I. Bryant, "Power Training: an Alternative Path to Conflict Management," California Management Review, Vol.21, No.2, pp.84-90, 1978.

[11] V. A. Thompson, "Hierarchy, Specialization, and Organizational Conflict," Administrative Science Quarterly, Vol.5, No.4, pp.487-521, 1961.

[12] A. Henry, "Constructive Role of Interorganizational Conflict," Administrative Science Quarterly, Vol.14, No.4, pp.573-583, 1969.

[13] 이재은, "위기관리 정책에 관한 연구: 개념, 영역, 정책결정을 중심으로”, 한국행정논집, 제 10 권, 제 1호, pp.113-130, 1998

[14] 지속가능발전위원회, 갈등관리시스템 구축방안 연구보고서, 지속가능발전위원회, 2004.

[15] 김경배, "한국 대체적 분쟁해결제도( $\mathrm{ADR})$ 의 제 도화 및 발전방안에 관한 연구”, 산업경제연구, 제18권, 제1호, pp,251-274, 2005.

[16] 이규진, "미국 $\mathrm{ADR}$ 에 비추어 본 우리나라의 $\mathrm{ADR}$ ”, 중재 제296호, pp.25-47, 2000.

[17] 김준한, “행정부와 대체적 분쟁해결제도”, 한국 행정학보, 제30권, 제4호, pp.37-53, 1996.

[18] 우동기, 장영두, “환경분쟁해결을 위한 대안적 분쟁해결제도 도입에 관한 기초연구”, 협상연구, 제5권, 제2호, pp.27-62, 1999.

[19] 정주용, "성공적 갈등해결전략으로써 협상의 성 공요인: 환경기초시설 빅딜사례를 중심으로”, 정 부학연구, 제 10 권, 제 1 호, pp.193-238, 2004.

[20] 정창수, 주택정책의 정책효과 분석에 관한 연구, 경희대학교 대학원 박사학위 논문, 2004.

[21] 라영재, 김세진, "사회운동이 정부정책 변화에 미치는 성공요인에 관한 연구: 화물연대 운송거 부 파업을 중심으로”, 한국행정학회, 2003 추계학 술대회 발표논문집, pp.390-404, 2003.

[22] 한국해양수산개발원, 화물연 대 운송거부사태의 영향과 정책과제, 해양수산 현안분석, 2003-6, 2003.

\section{저 자 소 개}

변 성 수(Sung-Soo Byun)

정회원

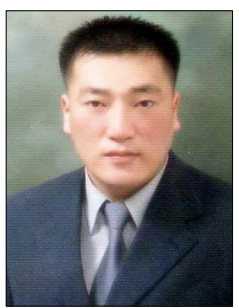

구원

<관심분야> : 정책집행, 조직이론, 위기관리, 갈등관 리

이 재 은(Jae-Eun Lee)

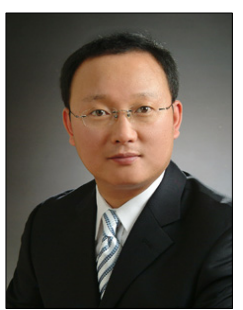

<관심분야> : 위기관리, 조직이론, 정책집행 정회원

- 2000년 2월 : 연세대학교 행정 학과(행정학박사)

- 현재 : 충북대학교 행정학과 부 교수

- 2006년 2월 : 충북대학교 대학 원 행정학과(행정학석사)

- 2008년 2월 : 충북대학교 대학 원 행정학과(박사과정 수료)

- 2006년 11월 현재 : 충북대 학교 국가위기관리연구소 선임연

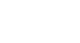

